\title{
Evaluation of the genetic variability among a wild peganum harmala L. populations with RAPD-PCR
}

\begin{abstract}
Forty wild individuals of wild Peganum harmala (P. harmala) were collected from four sites in Ma'an Governorate and were assessed for genetic variability by the method of random amplified polymorphic DNA (RAPD) PCR. Four primers produced 43 amplified bands and 23 of them were polymorphic. Miniature degree of genetic diversity was detected among studied population of wild P. harmala. Cluster analysis by the un weighted pair-group method with arithmetic averages (UPGMA) divided the wild populations into three main clusters, and one individual was identified in a separated group. It is apparent from this study that individuals of P. harmala species were more closely related. The RAPD markers detected sufficient degree of polymorphism to differentiate among the studied populations, making this technique valuable for wild types management and selectivity for breeding program.
\end{abstract}

Keywords: genetic diversity, jordan, polymorphism, RAPD

\author{
Volume I Issue 3 - 2017
}

\author{
Ibrahim Mohammad Al Rawashdeh,' Abdel \\ Rahman Twaha,' Yousef M Abu-Zaitoon,' \\ Nahed Marouf Ahmed, ${ }^{2}$ Khaleel IZ Jawasreh ${ }^{3}$ \\ 'Department of Biological Science,Al-Hussein Bin Talal \\ University, Jordan \\ ${ }^{2}$ Department of Biotechnologists, NCARE, Jordan \\ ${ }^{3}$ Department of Animal Production, University of Science and \\ Technology (JUST), Jordan
}

Correspondence: Ibrahim Mohammad AI Rawashdeh, Department of Biological Science, Al-Hussein Bin Talal University, P.O. Box (20), Maan, Jordan, Tel 009627 775। 44I7, Email irawashdeh2002@yahoo.com

Received: May 26, 2017 | Published: June 22, 2017

\section{Introduction}

P. harmala L. species is well known for its medicinal and traditional uses in folk medicine. Its extract was exposed against two cancer cell lines, MDA-MB-231 and Mcf-7, and that showed cell growth inhibition and in higher concentration/longer time, complete cell death occurred Tehrani et al. ${ }^{1}$ Assess the diversity of plant genetic resources (germplasm), that have a great chance to occurrence of useful genes, is the first essential prerequisite to plan for the conservation, sustainable use and domestication of them Khoshsokhan et al. ${ }^{2}$ Molecular markers such as random amplified polymorphic DNA Williams et al. ${ }^{3}$ may facilitate more effective diversity analysis of several plants. RAPD-PCR analysis has been used to evaluate the levels of genetic variation among diverse wild cranberry clones, ${ }^{4}$ genetic diversity of climbing species of palms Sramah et al., ${ }^{5}$ genetic diversity of a medicinal and aromatic plant Teucrium polium Boulila et al. ${ }^{6}$ genetic variability among five caraway populations Laribi et al., ${ }^{7}$ in Draba dorneri vascular plant Catană et al., ${ }^{8}$ among cowpea genotypes Patil et al., genetic diversity and related relationships among 22 landrace of Ficus carica L. sativa Ali-Shtayeh et al. ${ }^{10}$ and for Withania somnifera (L.) Sahu et al. ${ }^{11}$ Variability within and among genus, species and families are based on the genetic makeup, the natural selection, human interfering and nature calamities. In the study carried out on analysis of molecular variance of RAPD data of Aegilops geniculata populations and Triticum durum found that major proportion (80\%) of the total variation was existed within populations; in contrast, $20 \%$ of the variation was come from among populations Mahjoub et al. ${ }^{12}$ However, most RAPD loci are supposed to have only two alleles and separate as dominant markers, foremost to under evaluation of the genetic variation. Little is known about $P$. harmala genetic diversity either in the field or by using RAPD and most of studied concentrated on its pharmacological effects on certain diseases. Moreover, several studies were conducted for evaluation the genetic diversity within and among population of wild types of medicinal plants such as Teucrium polium populations, ${ }^{13}$ Lupinus pilosus L., ${ }^{14}$ cultivated tomato; ${ }^{15}$ Artemisia judaica ${ }^{16}$ and estimation of genetic variation within yellow asphodel individuals AlRawashdeh et al. ${ }^{15}$ Therefore, the aim of this study was to assess the level of genetic variability and differentiation among population of Peganum based on RAPD markers.

\section{Material and methods}

\section{Plant material and DNA isolation}

For this investigation, fresh leaves of a total 40 single individuals (10 samples per population) representing four populations were collected in April, 2015 from Ma'an Governorate. DNA was extracted from young leaves of $P$. harmala using CTAB method. Total genomic DNA was extracted from $5 \mathrm{~g}$ of leaf materials from each sample according to Bader et al. ${ }^{17}$ Leaf samples were kept in a fixing solution (95\% ethanol) for one hour, kept in oven over night then dried and homogenized in a mortar and pestle. Twenty $\mathrm{mg}$ of grinding tissues placed in $1.5 \mathrm{ml}$ tubes and mixed with $600 \mu \mathrm{l}$ of freshly prepared and preheated $2 \mathrm{x}$ CTAB solution in $2 \mathrm{ml}$ tubes then placed at $65^{\circ} \mathrm{C}$ for $60 \mathrm{~min}$. The mixture was added to $600 \mu 1$ of chloroform/isoamyl alcohol (24:1), vortexed for few seconds, and then centrifuged at $14,000 \mathrm{~g}$ for $15 \mathrm{~min}$. DNA was then precipitated with an equal volume of pre cooled ethanol $\left(-20^{\circ} \mathrm{C}\right)$, then centrifuged for $15 \mathrm{~min}$ at $14000 \mathrm{~g}$. The solution was poured in tubes and left to dry, then $600 \mu l$ of cooled $\left(4^{\circ} \mathrm{C}\right) 70 \%$ ethanol was added to the solution and placed in the refrigerator $\left(-20^{\circ} \mathrm{C}\right)$ overnight. Next day, ethanol was poured from the dried tubes and $100 \mu 1$ of TE buffer $(10 \mathrm{mM}$ Tris- $\mathrm{HCl}, 1 \mathrm{mMEDTA}$, $\mathrm{pH}$ 8.0) was added and the whole mixture were placed at $65^{\circ} \mathrm{C}$ for $60 \mathrm{~min}$. Four $\mu 1$ of RNAase $(10 \mathrm{mg} / \mathrm{ml})$ were added per tube and left for $60 \mathrm{~min}$ at $37^{\circ} \mathrm{C}$. The concentration of DNA was estimated using S2100 UV/VIS DIODE-Array-Spectrophotometer, machine Version 1.7. The purity was measured by the ratio of the absorbance at 260 and $280 \mathrm{~nm}$.

\section{PCR amplification}

PCR reaction was performed as described by Williams et al. ${ }^{3}$ with arbitrary ologonucleotides from Operon Technologies (Alameda, Calif.). The final volume of $25 \mu$ l contained $10 \mathrm{x}$ buffer $(50 \mathrm{mM} \mathrm{KCl}$, $10 \mathrm{mM}$ Tris- $\mathrm{HCl} \mathrm{pH} 8.3,1.5 \mathrm{mM} \mathrm{MgCl}$, and $0.001 \%$ (w/v) gelatin), 20ng of template DNA, $0.25 \mathrm{mM}$ dNTPs (Promega), $0.025 \mathrm{mM}$ 
of primers, $1.5 \mathrm{mM} \mathrm{MgCl}_{2}$ and $1 \mathrm{U}$ of Taq polymerase. Reaction mixtures were amplified in PCT-200 programmable thermo cycler (MJ Research Inc., USA), each reaction was performed using an initial step of $94^{\circ} \mathrm{C}$ followed by 44 cycles of a denaturation step for $1 \mathrm{~min}$ at $94^{\circ} \mathrm{C}$, followed by an annealing step for $1 \mathrm{~min}$ at $36^{\circ} \mathrm{C}$ and an extension step for $2 \mathrm{~min}$ at $72^{\circ} \mathrm{C}$, followed by a further extension step for $5 \mathrm{~min}$ at $72^{\circ} \mathrm{C}$. After the final cycle the samples were holding at $4{ }^{\circ} \mathrm{C}$ for analysis. Amplified fragments $10 \mu 1$ RAPD-PCR along with $100 \mathrm{bp}$ DNA ladder were resolved by electrophoresis on $1.4 \%$ a garose gel mixed with $2 \mu 1$ of ethidium bromide in $1 \mathrm{X}$ tris-borate-EDTA (TBE) buffer. Primer screening: twenty decamer primers from Operon, Advanced Biotechnologies Inc. Almeda, USA were firstly screened using one individual DNA sample represent a single plant to define the suitability of each primer for this study. After introductory testing on a few samples, four primers were selected for further analysis based on their ability to discover distinguish obviously resolved and bands within the population. The primers generating no and weak amplified fragments were dismissed.

\section{Data analysis}

The RAPD fragments were scored as present (1) or absent (0) for each of the markers to approximate the similarity among all populations and then transferred into a binary matrix. Each band was assumed to represent a single locus. All gels were scored for both monomorphic and polymorphic amplified fragments. The matrix of similarity was calculated using the Jaccards' coefficient ${ }^{18}$ and the dendrogram obtained by clustering according to the Unweighted PairGroup Method with arithmetic averages (UPGMA) using SPSS, V. (11.0), software. Genetic diversity within populations was estimated using the percentage of polymorphic bands [number of polymorphic bands/ number of total bands) x100].

\section{Results}

The $P$. harmala populations were collected to assess the genetic variability at the DNA level. Random amplified polymorphic DNA (RAPD) analysis has been demonstrated as a good tool for this aim.
Initially, RAPD analysis was passed out using asset of more than 25 random primers of Opern Kits A, B, F, W and Z, for amplification during PCR. Among them, four RAPD primers produced polymorphic amplified fragments except one primer did not yield any polymorphic bands (Table 1). A representative banding pattern is shown in (Figure 1A), which demonstrates a total of 43 diverse bands from four populations of $P$. harmala. The primer (ACAACGCCTC) and (CCGTGACTCA) showed the highest percentage of polymorphism $(75 \%)$ and $(63 \%)$, respectively (Table 1$)$. The primer P1 shows the highest number (8) of polymorphic bands followed by P2, which shows 6 bands. Most of similarity among testing samples were ranged between 1.00-0.58 (Table 2). The dendrograms depended on the Jaccard's coefficients values (Figure 1B) and is investigative of low to medium level of polymorphism among the four populations at the DNA level. The samples of $P$. harmala were grouped into two major clusters. The first cluster (A) was divided into 5 sub-clusters (A1-A5) (Figure 2). The first sub-cluster was then divided into three main sub-sub clusters. The first sub-sub cluster contained 5 samples from Alshoubak, one sample of Adruh, one Wadimusa sample (Figure 2). Among these samples (0.93) similarity was formed between two samples 33, 36 Alshoubak regions, 31, 33 Alshoubak site, Adruh sample 13 and Wadimusa sample 23 had 1.00 similarities. Also two Adruh samples (14 and 15) showed 1.00 similarity values (Figure 2). The second sub-sub cluster consists of two samples of Alshoubak, one samples of Ma'an and one sample Wadimusa. The third sub-sub cluster formed 4 Wadimusa sample, 8 Adruh and 3 of Ma'an site. The second sub-sub cluster appeared two Ma'an samples, one of Adruh individuals and one sample Wadimusa. The third sub-sub cluster integrated three Wadimusa. The forth sub-sub cluster enclosed three of Ma'an individuals and two of Alshoubak samples. The fifth subsub cluster had only one samples of Alshoubak region. The second main cluster formed a separate cluster and showed only one individual (no.2) collected from Ma'an site (Figure 2), formed diverse cluster compared to the rest of individuals. Variability among populations was existed through distribution the sites samples overall the clusters. Variation within sites was observed but with a low level.

Table I Primer sequence and monomorphic and polymerphic bands obtained by using four RAPD primers

\begin{tabular}{llllll}
\hline Primer name & Primer sequence & Band total & Monomorphic & Polymorphic & \% Polymorphism \\
\hline OPA-14 & TCTGTGCTGG & 8 & 4 & 4 & 50 \\
OPM-02 & ACAACGCCTC & 8 & 2 & 6 & 75 \\
OPM-07 & CCGTGACTCA & 8 & 3 & 5 & 63 \\
OPM-06 & CTGGGCAACT & 6 & 6 & 0 & 0 \\
\hline
\end{tabular}

$1234567891011121314151617181920212223242526 \mathrm{M}$

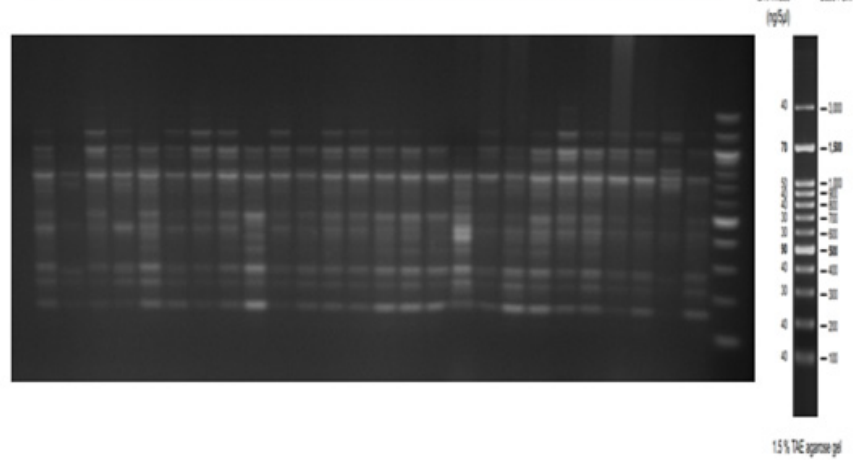

Figure I A representative RAPD banding profiling using OPM-02primer among different populations of Peganum harmala species. M: I00bp DNA ladder (Gene Direx). 


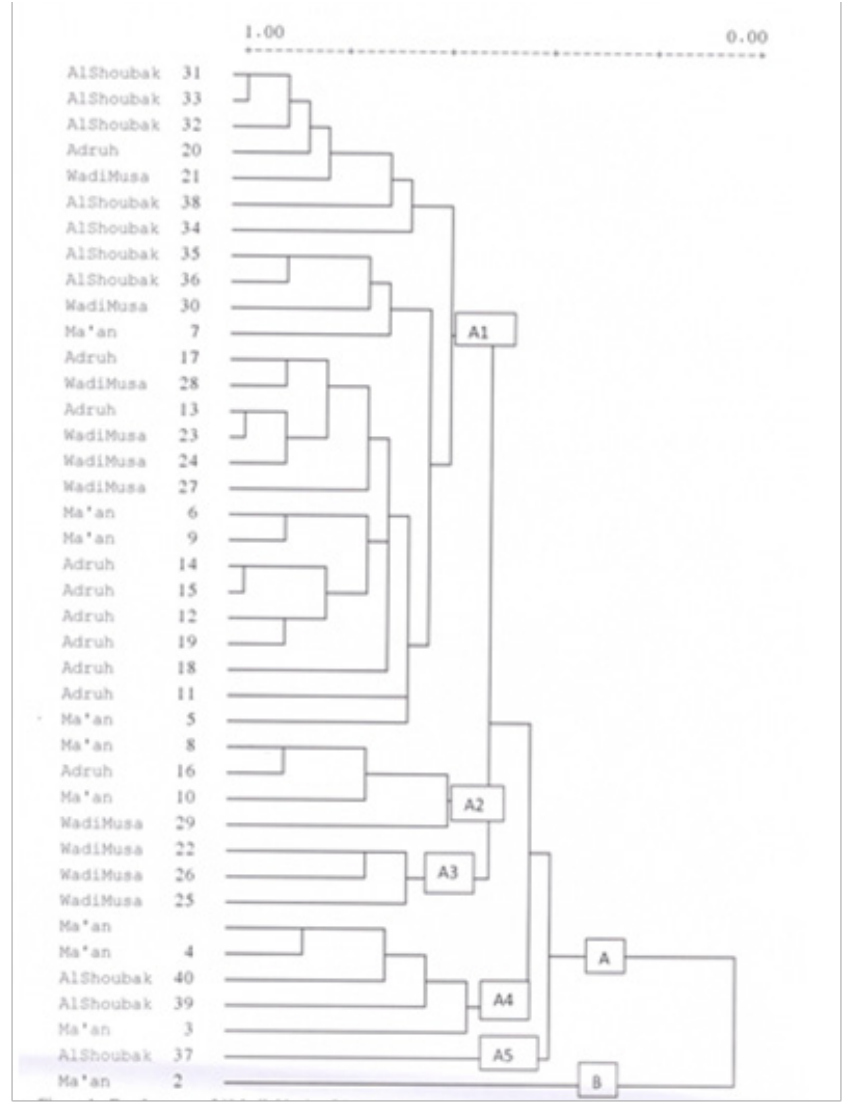

Figure 2 Dendrogram 40 individual of $P$ haramala constructed by UPGMA on RAPD banding patterns.

\section{Discussion}

P. harmala L. is wild plant species and contain major alkaloid compounds such as harmaline and harmine that are used in pharmaceuticals and medicines. This species is distributed all over the Jordan. It is significant that all population samples from diverse locations in and around Ma'an city in southern part of Jordan were separated into discrete group, that confirmed the presence of low level of genetic variation in studied species in a small geographical area. The existence of low genetic variability within this species has been mostly attributed to self-pollination along with environmental pressure. Moreover, endurance of little variation referred to scarcity of natural selection pressure, lessen mutation rate and short life span of $P$. harmala species. Knowledge of genetic diversity within a population is important for the conservation of the species Catană et al. ${ }^{8}$ Darokar et al. ${ }^{19}$ found that all accessions of Bacopa monnieri from different locations in and around city of Pune, India formed separated group. Presence of variation within populations or among them could be related to dissimilarity in the microenvironments of habitats for this species. The wild heritable phenotypic and chemotypic variation observed in the collection of accessions might be due to qualitative genetic differences Darokar et al. ${ }^{19}$ But the resemblance between populations indicated that they have harmonizing microenvironments of the habitats. Moreover, the likeness between geographical area emphasized that seeds of $P$. harmala were migrated by winds or though urbanization or tribes settlement. The level of genetic variation within a population differed according to the bioclimates and the cytotypes Boulila et al. ${ }^{6}$ Also, they suggested that the AMOVA conducted at the three hierarchical levels (population, ecological, and ploidal group) showed that most of the total variation was found among individuals within populations or within populations in their corresponding group. This suggests that mating occurs mainly among individuals within a subpopulation, thus favoring the divergence between populations. Sarmah et al..$^{5}$ reported that the RAPD markers grouped Rattan species collected in their specific species level with some exceptions and discovered intra-specific diversity. Our results showed that the similarity represented by the polymorphism of RAPD bands between individuals from the four sites of Ma'an governorate is approximately $63 \%$ (sample 1,3 ). In spite of the small size of the population, which usually reveals lower levels of genetic diversity, our findings based on the RAPD technique showed that the genetic diversity of this species is not low. However, this study showed that the groupings of populations were mostly in agreement with their geographical localities assigned the low level of genetic variation within populations. The occurrences of polymorphism within or among studied $P$. harmala populations point to potential of using RAPDs in category the genotypes. This study provides leadership for the prospective analysis of genetic diversity in Peganum species with even more consistent molecular markers such as AFLP and ISSR. To conclude, this is the first report on the evaluation of genetic variability and population discrimination analysis in four P. harmala species, mainly originating from Jordan using RAPD. We successfully provided deep insights in the genetic background of the studied populations. Considerable genetic variability has been detected at low level within or between populations. Further studies are needed to cover all science areas associated with this specie in the future.

\section{Acknowledgements}

None.

\section{Conflict of interest}

The author declares no conflict of interest.

\section{References}

1. Tehrani SSH, Somayeh Hashemi, Sheikh Shabani, et al. Growth inhibitory impact of Peganum harmala L. on two breast cancer cell lines. Iranian Journal of Biotechnology. 2014;12(1):8-14.

2. Khoshsokhan F, Babalar M, Fatahi M, et al. Assessment of genetic diversity of some wild populations of Thymus kotschyanus using RAPD molecular markers. Cercetări Agronomice în Moldova. 2014;3(159):7181.

3. Williams JG, Kubelik AR, Livak KJ, et al. DNA polymorphisms amplified by arbitrary primers are useful as genetic markers. Nucleic Acids Res. 1990;18(22):6531-6535.

4. Debnath SC. An assessment of the genetic diversity within a collection of wild cranberry (Vaccinium macrocarpon Ait.) clones with RAPD-PCR. Genetic Resources and Crop Evolution. 2007;54(3):509-517.

5. Sarmah P, Barua PK, Sarma RN, et al. Genetic diversity among rattan genotypes from India based on RAPD-marker analysis. Genet Resour Crop Evol. 2007;54(3):593-600.

6. Boulila A, Afef Bejaoui, Chokri Messaoud, et al. Genetic diversity and population structure of Teucrium polium (Lamiaceae) in Tunisia. Biochem Genet. 2010;48(1-2):57-70.

7. Laribi B, Nejia Zoghlami, Myriam Lamine, et al. RAPD-based assessment of genetic diversity among annual caraway(Carum carvi) populations. EurAsian Journal of BioSciences. 2011;5:37-47. 
8. Catană R, Monica Mitoi, Roxana Ion. The RAPD techniques used to assess the genetic diversity in Draba dorneri, a critically endangered plant species. Advances in Bioscience and Biotechnology. 2013;4(2):164-169.

9. Patil V, Subhash Sharma, Sampat Kalaskar, et al. Assessment of diversity among cowpea (Vigna unguiculata (L.) Walp) genotypes based on RAPD analysis. Electronic Journal of Plant Breeding. 2015;6(2):403-411.

10. Ali-Shtayeh M, Rana M Jamous, Salam Y Abu Zaitoun, et al. Genetic diversity of the Palestinian Fig (Ficus carica L.) collection by pomological traits and RAPD Markers. American Journal of Plant Sciences. 2014;5(9):1139-1155.

11. Sahu V, Dodiya NS, Joshi A, et al. Genetic diversity among Withania somenifera (L.) dunal genotypes using morphological and molecular markers. Journal of Cell and Tissue Research. 2015;15(1):4867-4875.

12. Mahjoub AA, Kaled Mguis, Mustapha Rouaissi, et al. RAPD analysis of genetic diversity in natural populations of Aegilops geniculata Roth and Triticum durum Desf. from Tunisia. Agric and Biol J N Am. 2012;3(1):466-475.

13. Ibrahim Mohammad AlRawashdeh. Genetic variability among and within wild Teucrium ploium populations at Wadi Shueib area in Jordan. Journal of Agricultural and Biological Science. 2015;10(7):267-273.
14. Ibrahim Mohammad AlRawashdeh, Nasab Q AlRawashdeh. Evaluation the genetic relatedness within Lupinus pilosus L. based on RAPD analysis. Jordan Journal of Biological Sciences. 2015;8 (1(:61-64.

15. Ibrahim Mohammad Al Rawashdeh, Abdel Rahman Mohammad Tawaha, Saleem Hmoud Aladaileh, et al. Estimation of genetic variation within yellow asphodel individuals using RAPD technique. Crop Research Journal. 2016;15(6):124-128.

16. Ibrahim Mohammad AlRawashdeh. Genetic variability in a medicinal plant Artemisia judaica using random amplified polymorphic DNA (RAPD) markers. International Journal of Agriculture and Biology. 2011;13(2):279-282.

17. Badar A, Abo Z El-Khier, Ghada A Hegazi, et al. Genetic Variation in Seven Natural Populations of Artemisia judaica L. in South Sinai Using RAPD Markers. World Applied Sciences Journal. 2012;18(10):14751480 .

18. Jaccard P. Nouvelles recherches sur la distribution florale. bulletin del la societe vaudoise. Des Sciences Naturelles. 1908;44:223-270.

19. Darokar MP, Suman PS, Khanuja, et al. Low levels of genetic diversity detected by RAPD analysis in geographically distinct accessions of Bacopa monnieri. Genetic Resources and Crop Evolution. 2001;48(6):555-558 